\title{
ANALISIS JAWABAN TUGAS MAHASISWA PADA TUTORIAL ONLINE BERDASARKAN BLOOM'S TAXONOMY
}

\author{
Sandra S. Adji (sandra@ut.ac.id) \\ Universitas Terbuka, Jl. Cabe Raya, Pondok Cabe, Pamulang 15418, Tangerag Selatan
}

\begin{abstract}
ABSTRAK
Universitas Terbuka (UT) yang disediakan oleh staf pendidikan dari Universitas Terbuka (UT) untuk membantu siswa mengatasi kesulitan belajar mereka. Makalah ini berfokus pada kemampuan siswa dalam melakukan tugas, yang diberikan oleh guru selama kegiatan tutorial online. Penelitian dilakukan di UT kegiatan program tutorial Kimia Lingkungan Subjek pada masa percobaan 2010.2, 2.011,1 2.011,2, 2.012,1 dan 2.012,2 melibatkan 81 siswa. Data diperoleh berdasarkan jawaban siswa terhadap tugas / tugas yang diberikan oleh tutor. Indikator yang digunakan untuk analisis siswa jawaban tugas yang siswa kemampuan dalam taksonomi Bloom menganalisis. Data kemudian dianalisis menjadi deskriptif kualitatif. Hasil penelitian menunjukkan: 1) Semua siswa mampu menjawab dengan baik untuk kemampuan pemahaman memori dan pemahaman 2). Tidak semua siswa mampu mencapai yang lebih tinggi berpikir tingkat yaitu menganalisis dan mengevaluasi dalam menjawab pertanyaan-pertanyaan yang diberikan. 3) Siswa memberikan respon positif dalam kegiatan tutorial online dan menggunakan "sumber daya terbuka pendidikan".
\end{abstract}

Kata kunci: kemampuan siswa, tugas selesai, tutorial online

\begin{abstract}
The Open University (UT) provided by the educational staff of the Open University (UT) to help students overcome their learning difficulties. This paper focuses on the ability of students in doing the tasks, assigned by the tutor during the online tutorial activities. The study was conducted at the UT course tutorial activities of Environmental Chemistry Subject at the trial period of 2010.2, 2011.1 2011.2, 2012.1 and 2012.2 involving 81 students. Data was obtained based on students' answers to the assignments/tasks given by the tutor. The indicators used for analysis of students' task answer were the students' ability in Bloom's taxonomy analyzing. The data then was analyzed into qualitative descriptive. Results showed: 1) All students were able to answer well for the ability of memory understanding and comprehension 2). Not all students were capable to reach higher level thinking i.e. analyzing and evaluating in answering the questions given. 3) Students gave positive respon in online tutorial activities and using the "open educational resources".
\end{abstract}

Keywords: online tutorial, tasks completion, students' ability

Mahasiswa Fakultas Keguruan dan IImu Pendidikan (FKIP) Universitas Terbuka (UT) adalah mereka yang telah bekerja menjadi pendidik (guru) dan tersebar di seluruh Indonesia, baik yang bertempat tinggal di perkotaan maupun di daerah-daerah. Universitas Terbuka sebagai lembaga pendidikan tinggi jarak jauh menggunakan jaringan internet sebagai salah satu modus pemberian pembelajarannya. 
Salah satu program pembelajaran yang disediakan oleh UT adalah bantuan belajar di antaranya adalah tutorial online (tuton). Hampir seluruh matakuliah yang ditawarkan di UT, disediakan fasilitas tutorial online. Kimia Lingkungan dengan kode mata kuliah PEKI 4312 merupakan salah satu matakuliah yang disediakan tutonnya sejak tahun 2007. Bentuk kegiatan tutorial yang diberikan adalah penyajian materi inisiasi yang berpedoman pada Buku Materi Pokok Kimia Lingkungan serta sumber belajar lain yang mendukung. Selain inisiasi juga diberikan tugas dan dikembangkan suatu interaksi antara mahasiswa dengan tutor dan mahasiswa dengan mahasiswa dalam bentuk forum diskusi. Dengan diberikannya tuton, diperlukan suatu informasi tentang hasil belajar yang telah dicapai pada pembelajaran dan respon mahasiswa terhadap kegiatan tuton tersebut.

Makalah ini bertujuan untuk memberikan informasi tentang penyelenggaraan kegiatan tuton matakuliah Kimia Lingkungan selama empat masa registrasi yaitu masa registrasi 2010.2, sampai dengan 2012.2, secara khusus ingin dijabarkan tentang: (1) partisipasi mahasiswa dalam mengikuti tutorial online, (2) pencapaian hasil belajar mahasiswa dalam menyelesaikan tugas yang diberikan, dan (3) respon mahasiswa dalam mengikuti tutorial online.

Data dikumpulkan dari 81 jawaban tugas mahasiswa selama empat masa registrasi serta respon yang diberikan oleh mahasiswa melalui kuesioner yang diberikan secara online. Data diperoleh berdasarkan kegiatan tuton yang berlangsung yang dapat diakses melalui http://student.ut.ac.id/mod/statut, pada masa registrasi berjalan dan selanjutnya dianalisis secara deskriptif.

\section{HASIL DAN PEMBAHASAN}

\section{Partisipasi Mahasiswa pada Kegiatan Tutorial On line}

Partisipasi mahasiswa dalam kegiatan tuton tidak hanya ditandai dengan mahasiswa melakukan aktivasi namun mahasiswa harus aktif melakukan serangkaian kegiatan tutorial seperti membuka/membaca inisiasi dan tugas, mengerjakan tugas yang dan mengunggahnya, serta melakukan diskusi baik dengan tutor maupun dengan sesama mahasiswa. Gambar 1 menunjukkan bahwa mahasiswa yang telah mengaktivasi sebagian besar di antaranya telah berpartisipasi aktif dalam kegiatan tutorial karena mahasiswa mengerjakan tugas yang diberikan. Meskipun sebagian lainnya hanya membuka satu kali atau dikenal dengan istilah mengaktivasi.

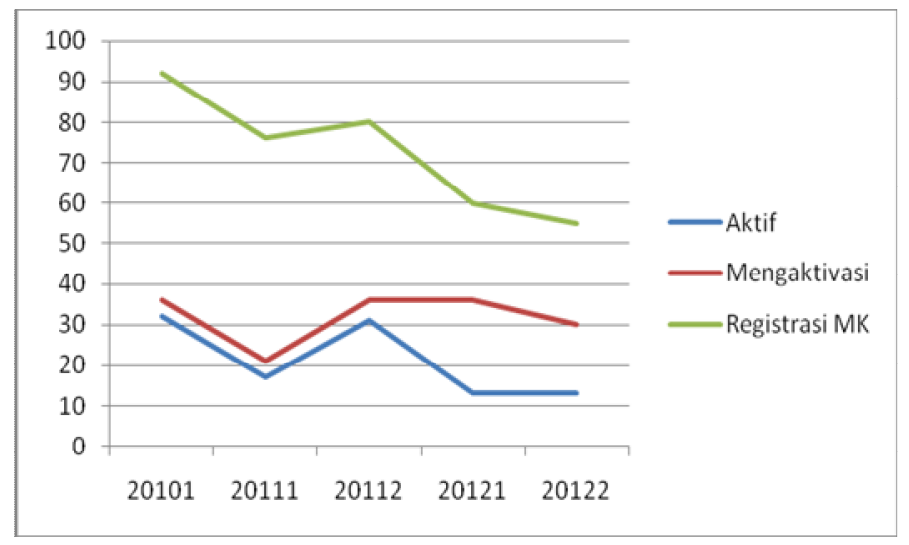

Gambar 1. Partisipasi mahasiswa dalam kegiatan tutorial online matakuliah kimia lingkungan 
Pada Gambar 1 tampak bahwa belum seluruh mahasiswa terlibat dalam kegiatan tutorial online. Melalui gambar tersebut dapat diterangkan bahwa di antara mahasiswa yang meregistrasi matakuliah Kimia Lingkungan, terdapat mahasiswa yang mengikuti tutorial online hanya 15 sampai dengan $40 \%$. Kondisi ini diduga belum seluruh mahasiswa memerlukan bantuan belajar atau sibuk bekerja karena mereka bertugas sebagai guru. Hal ini seperti ditunjukkan dengan partisipasi mahasiswa dalam mengerjakan tugas tutorial online. Pada Tugas 1 hampir seluruh mahasiswa mengumpulkan tugas sementara pada Tugas 2 dan Tugas 3 menjadi berkurang dan bahkan mendekati separuhnya, sementara tugas tersebut memberi kontribusi terhadap nilai akhir tutorial online. Partisipasi mahasiswa dalam mengirimkan/mengumpulkan/meng-upload tugas seperti tertera pada Gambar 2.

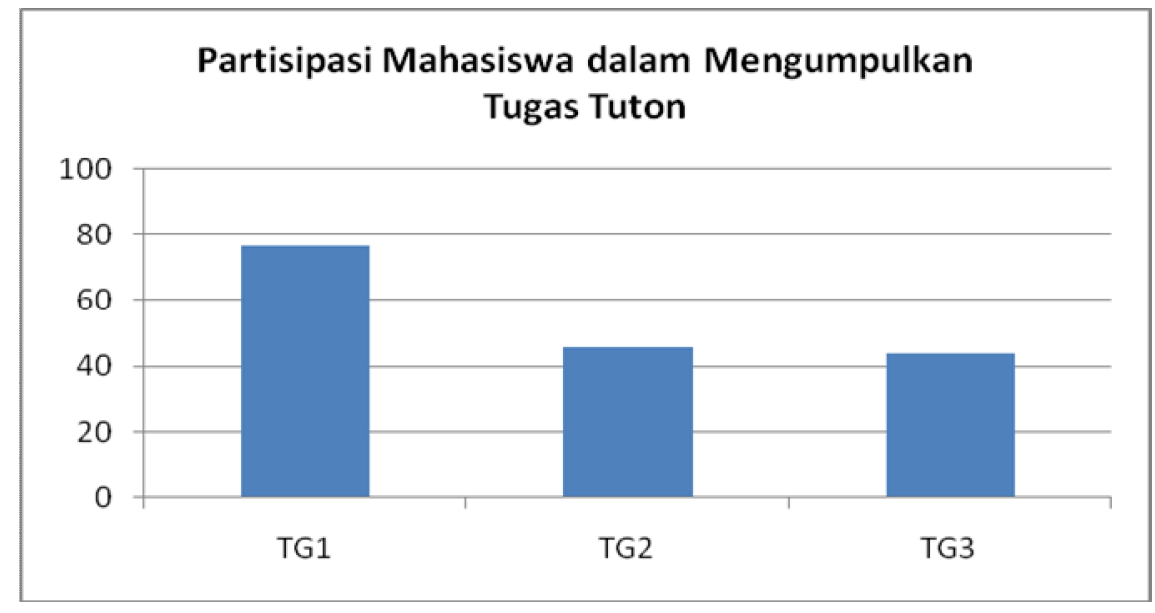

Gambar 2. Partisipasi mahasiswa dalam mengirimkan tugas tuton

Sementara sampai dengan masa registrasi 2012.2, mahasiswa belum diwajibkan mengikuti kegiatan tuton, sehingga memungkinkan mahasiswa untuk tidak mengikuti tutorial online cukup besar. Dugaan lain kurang aktifnya mahasiswa dalam mengikuti tutorial online adalah terdapat mahasiswa yang mengalami hambatan akses ke komputer dan jaringan. Hal ini seperti ditunjukkan oleh respon mahasiswa sebagai berikut:

"Pertama kali membuat tugas, tugas 1 dan 2 saya tidak bisa akses internet, terlambat" (Dwito, 2011.2).

"Internet sangat berguna dalam men-download dan berguna sekali untuk pengetahuan. Kendala yang saya hadapi adalah apabila mengerjakan tugas harus pergi ke warnet,karena tidak punya laptop, jadi ya harus ngantri sesama pemakai internet, cara penyajian tugas dalam internet, bisa saya ikuti" (Sumantri Budhi Setyanto, 2012.1).

Pada kegiatan tutorial online kepada mahasiswa diberikan 8 materi inisiasi dan 3 tugas selama satu semester atau periode tutorial online. Bentuk inisiasi yang diberikan bervariasi, dan umumnya dalam bentuk power point. Pada inisiasi terdapat beberapa rujukan yang dapat diperoleh melalui 'Open Educational Resource” (OER), dan biasanya berbentuk video, gambar atau artikel. 
Selain diberikan materi inisiasi kepada mahasiswa juga diberikan tiga tugas yang disampaikan pada minggu ke 3, 5 dan 7 kegiatan tutorial online. Dalam inisiasi juga dijabarkan kompetensi yang ingin dicapai melalui kegiatan tutorial online tersebut.

\section{Pencapaian Hasil Belajar Mahasiswa Peserta Tutorial Online}

Hasil belajar mahasiswa dalam kegiatan tutorial online ditunjukkan melalui penyelesaian tugas tutorial yang diberikan. Jabaran butir soal yang diberikan mengacu pada pencapaian kompetensi matakuliah. Mahasiswa harus mengunggah jawaban tugas pada jendela yang tersedia pada tampilan tutorial online. Hasil analisis data dengan menggunakan jenjang kemampuan berfikir kognitif yaitu taksonomi yang dikembangkan oleh Bloom's adalah remembering, understanding, applying, analyzing, evaluating and creating (L.W. Anderson and D.R. Krathwol, 2001). Pada materi tutorial online matakuliah Kimia Lingkungan terdapat contoh pertanyaan dan contoh jawaban mahasiswa seperti tertera pada Tabel 2.

Tabel 2. Contoh Pertanyaan pada Tugas Tuton dan contoh Jawaban Mahasiswa

\begin{tabular}{ll}
\hline $\begin{array}{l}\text { Contoh } \\
\text { Pertanyaan }\end{array}$ & $\begin{array}{l}\text { Jenjang } \\
\text { Kemampuan }\end{array}$ \\
\hline "Apa yang & C1 Ingatan \\
dimaksud & \\
dengan & \\
pencemaran & \\
lingkungan?" & \\
"Apa yang & C2 Pemahaman \\
dimaksud & \\
dengan Efek & \\
Rumah Kaca & \\
(ERK) dan & \\
penyebabnya? & \\
"
\end{tabular}
Contoh Jawaban Mahasiswa Pencemaran Lingkungan adalah masuknya atau dimasukkannya makhluk hidup, zat, energi, dan atau komponen lain ke dalam lingkungan oleh kegiatan manusia atau oleh proses alam sehingga kualitas lingkungan turun sampai ke tingkat tertentu yang menyebabkan lingkungan menjadi kurang atau tidak berfungsi lagi sesuai dengan peruntukkannya.

"Efek rumah kaca adalah efek kenaikan suhu di dalam ruang rumah kaca yang disebabkan terperangkapnya sinar infra merah oleh kaca. Penyebab Efek Rumah Kaca:

Efek rumah kaca terjadi karena sinar matahari dengan panjang gelombang yang paling panjang (sinar infra merah) yang memanasi bumi akan dipantulkan oleh benda-benda yang ada di permukaan bumi tidak diteruskan ke angkasa, namun sinar infra merah ini akan diserap oleh gas-gas yang ada di lapisan atmosfer terendah, yaitu troposfer. Gas-gas yang ada dilapisan troposfer yang dapat menyerap sinar infra merah adalah gas $\mathrm{CO}_{2}$, uap air, ozon yang jumlahnya sedikit, debu, asap dan gas-gas lain. Sinar infra merah ini terperangkap dan tersimpan di dalam troposfer di atas permukaan bumi. Panas dari sinar matahari (sinar infra merah) yang terperangkap dan tersimpan di dalam lapisan troposfer di atas permukaan bumi meningkat. Sebagian matahari yang dapat mencapai bumi yaitu radiasi dengan panjang gelombang panjang, yaitu sinar infra merah (14.000-24.000 nm) menembus masuk atap dan dinding rumah kaca. Di dalam rumah kaca sinar ini dipantulkan oleh benda-benda yang ada di rumah kaca, tetapi tertahan oleh atap dan dinding kaca. Oleh karena itu, udara di dalam rumah kaca suhunya meningkat lebih tinggi dari pada suhu di luar rumah kaca. Efek rumah kaca ini bisa juga terjadi di dalam ruangan rumah dengan jendela kaca lebar atau terkena sinar matahari atau di dalam mobil dengan jendela tertutup apabila diparkir di tempat yang panas" 
Tabel 2. Lanjutan

\begin{tabular}{|c|c|c|}
\hline $\begin{array}{l}\text { Contoh } \\
\text { Pertanyaan }\end{array}$ & $\begin{array}{l}\text { Jenjang } \\
\text { Kemampuan }\end{array}$ & Contoh Jawaban Mahasiswa \\
\hline $\begin{array}{l}\text { "Buat contoh } \\
\text { ilustrasi } \\
\text { perhitungan } \\
\text { batas } \\
\text { maksimum } \\
\text { penggunaan } \\
\text { bahan }\end{array}$ & C3 Penerapan & $\begin{array}{l}\text { ADI dihitung berdasarkan berat badan konsumen dan sebagai standar } \\
\text { digunakan berat badan } 50 \mathrm{~kg} \text { untuk negara Indonesia. Satuan ADI adalah mg } \\
\text { bahan tambahan makanan per } \mathrm{Kg} \text { berat badan. } \\
\text { Contoh llustrasi : } \\
\text { Jika diketahui ADI suatu makanan yang mengandung asam benzoat adalah } 5 \\
\mathrm{mg} / \mathrm{Kg} \text {. Hitunglah batas penggunaan maksimum (BPM) bahan tersebut jika } \\
\text { berat bahan } 1000 \mathrm{mg} \text { dan bobot badan orang yang mengonsumsinya } 50 \mathrm{Kg} \text { ? }\end{array}$ \\
\hline $\begin{array}{l}\text { tambahan } \\
\text { pangan bagi } \\
\text { tubuh manusia } \\
\text { sesuai dengan } \\
\text { Acceptable } \\
\text { Daily Intake } \\
\text { (ADI). Atau } \\
\text { dapat pula } \\
\text { Anda mencoba } \\
\text { membuat } \\
\text { contoh } \\
\text { perhitungan } \\
\text { batas } \\
\text { maksimum } \\
\text { penggunaan } \\
\text { bahan } \\
\text { tambahan } \\
\text { pangan saos } \\
\text { tomat sesuai } \\
\text { ADI". }\end{array}$ & & 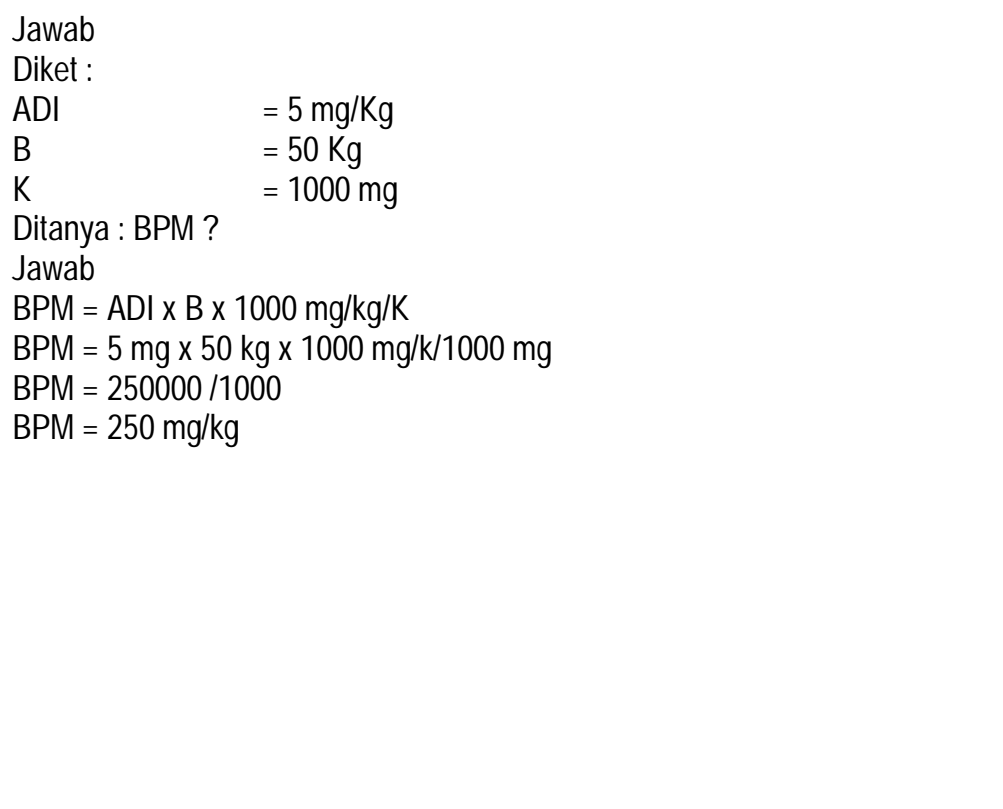 \\
\hline $\begin{array}{l}\text { "Unsur-unsur } \\
\text { apa yang } \\
\text { cenderung } \\
\text { mencemari } \\
\text { tanah dan dari } \\
\text { mana asalnya } \\
\text { (sumber- } \\
\text { sumbernya)" }\end{array}$ & C4 Analisis & $\begin{array}{l}\text { Pencemaran pada tanah tidak selalu diakibatkan kerusakan dari tanah itu } \\
\text { sendiri namun umumnya sangat berhubungan dengan pencemaran udara } \\
\text { dan pencemaran air. Sumber bahan pencemar di antaranya diperoleh dari } \\
\text { sampah ( rumah tangga, industri, dan rumah sakit), dampak industri, } \\
\text { penggunaan pupuk dan pestisida serta reaktor atom. }\end{array}$ \\
\hline $\begin{array}{l}\text { "Apakah } \\
\text { penipisan } \\
\text { lapisan ozon } \\
\text { ada } \\
\text { hubungannya } \\
\text { dengan } \\
\text { Pemanasan } \\
\text { Global dan } \\
\text { perubahan } \\
\text { Iklim?" }\end{array}$ & C5 Evaluasi & $\begin{array}{l}\text { Menurut saya penipisan lapisan ozon tidak ada hubungan dengan } \\
\text { pemanasan global dan perubahan iklim. } \\
\text { Penipisan lapisan ozon, pemanasan global dan perubahan iklim merupakan } \\
\text { dua masalah yang berbeda tetapi berkaitan satu sama lainnya. Beberapa } \\
\text { polutan (zat pencemar) pada pemanasan global dan perubahan iklim } \\
\text { memberikan kontribusi yang sama terhadap penipisan lapisan ozon. Dengan } \\
\text { menipisnya lapisan ozon, maka ultra violet (UV) akan meningkat di } \\
\text { permukaan bumi sehingga akan terjadi pemanasan global dan perubahan } \\
\text { iklim. }\end{array}$ \\
\hline
\end{tabular}


Tabel 2. Lanjutan

\begin{tabular}{|c|c|c|}
\hline $\begin{array}{l}\text { Contoh } \\
\text { Pertanyaan }\end{array}$ & $\begin{array}{l}\text { Jenjang } \\
\text { Kemampuan }\end{array}$ & Contoh Jawaban Mahasiswa \\
\hline & & $\begin{array}{l}\text { Pemanasan global dan perubahan iklim sesungguhnya berbeda dengan } \\
\text { resiko yang dihadapi manusia dari akibat penipisan lapisan ozon. } \\
\text { Penipisan lapisan ozon mengakibatkan meningkatnya UV ke permukaan } \\
\text { Bumi, namun meningkatnya UV di permukaan bumi bukanlah penyebab } \\
\text { terjadinya pemanasan global, melainkan kanker kulit, katarak, menurunnya } \\
\text { kekebalan tubuh, dan menurunnya hasil panen. } \\
\text { Penipisan lapisan ozon sangat berhubungan dengan pemanasan global dan } \\
\text { perubahan iklim, gas rumah kaca dapat merusak lapisan ozon, sehingga } \\
\text { terjai satu fenomena dimana gelombang pendek radiasi matahari menembus } \\
\text { atmosfer dan berubah menjadi gelombang-gelombang panjang mencapai } \\
\text { permukaan bumi. Setelah mencapai permukaan bumi, sebagian gelombang } \\
\text { tersebut dipantulkan kembali ke atmosfer. Namun tidak seluruh gelombang } \\
\text { yang dipantulkan itu dilepaskan ke angkasa luar. Sebagian gelombang } \\
\text { panjang dipantulkan kembali oleh lapisan gas rumah kaca di atmosfer ke } \\
\text { permukaan bumi. Proses ini dapat berlangsung berulang kali, dan gelombang } \\
\text { masuk juga terus-menerus bertambah. Akibatnya, terjadi akumulasi panas di } \\
\text { atmosfer. Hal ini dapat meningkatkan suhu di permukaan laut. Suhu di } \\
\text { permukaan laut yang meningkat dapat mempengaruhi tekanan udara dan } \\
\text { angin. Sehingga terjadi perubahan iklim. } \\
\text { Lapisan ozon berfungsi untuk menyerap radiasi dari sinar matahari yang } \\
\text { akan masuk ke Bumi. Tipisnya lapisan ozon mengakibatkan radiasi yang } \\
\text { berbahaya lebih banyak masuk ke permukaan bumi. Hal ini berdampak pada } \\
\text { meningkatnya suhu bumi karena setelah radiasi sampai ke Bumi, radiasi } \\
\text { dipantulkan ke atmosfir tetapi di atmosfir radiasi dipantulkan kembali ke bumi } \\
\text { sehingga suhu bumi meningkat } \\
\text { Penipisan lapisan Ozon ada hubungan dengan perubahan iklim dan } \\
\text { pemanasan global }\end{array}$ \\
\hline $\begin{array}{l}\text { "Saudara } \\
\text { mahasiswa } \\
\text { selanjutnya } \\
\text { carilah artikel } \\
\text { tentang } \\
\text { Acceptable } \\
\text { Daily Intake } \\
\text { (ADI) dari } \\
\text { sumber- } \\
\text { sumber yang } \\
\text { dapat } \\
\text { didownload } \\
\text { dari internet. } \\
\text { Dan Jangan } \\
\text { lupa } \\
\text { cantumkan } \\
\text { sumbernya } \\
\text { serta beri } \\
\text { ulasan Anda } \\
\text { tentang materi } \\
\text { tersebut". }\end{array}$ & C6 Kreativitas & Sumber http://pipimm.or.id/food info.php?view=1\&id=52 \\
\hline
\end{tabular}




\section{ULASAN ARTIKEL}

Zat tambahan makanan atau yang sering dikenal dengan zat aditif adalah zat yang ditambahkan dan dicampurkan dalam pengolahan makanan untuk meningkatkan mutu. Jenis-jenis zat aditif antara lain pewarna, penyedap rasa, penambah aroma, pemanis, pengawet, pengemulsi dan pemutih. Zat aditif pada makanan ada yang berasal dari alam dan ada yang buatan (sintetik). Untuk zat aditif alami tidak banyak menyebabkan efek samping. Lain halnya dengan zat aditif sintetik. Penggunaan bahan makanan pangan tersebut di Indonesia telah ditetapkan oleh pemerintah berdasarkan Undang-undang, Peraturan Menteri Kesehatan dan lain-lain disertai dengan batasan maksimum penggunaannya. Di samping itu UU Nomor 7 tahun 1996 tentang Pangan Pasal 10 ayat 1 dan 2 beserta penjelasannya erat kaitannya dengan bahan tambahan makanan yang pada intinya adalah untuk melindungi konsumen agar penggunaan bahan tambahan makanan tersebut benarbenar aman untuk dikonsumsi dan tidak membahayakan. Namun demikian penggunaan bahan tambahan makanan yang melebihi ambang batas yang ditentukan ke dalam makanan atau produkproduk makanan dapat menimbulkan efek samping yang tidak dikehendaki dan merusak bahan makanan itu sendiri, bahkan berbahaya untuk dikonsumsi manusia. Semua bahan kimia jika digunakan secara berlebih pada umumnya bersifat racun bagi manusia. Tubuh manusia mempunyai batasan maksimum dalam mentolerir seberapa banyak konsumsi bahan tambahan makanan yang disebut Acceptable Daily Intake (ADI). ADI menentukan seberapa banyak konsumsi bahan tambahan makanan setiap hari yang dapat diterima dan dicerna sepanjang hayat tanpa mengalami resiko kesehatan. Begitu pula dengan pemanis buatan seperti aspartam, sakarin, Acesulfame K dan Sucralose, penggunaannya harus sesuai dengan standar yang telah ditentukan. Meskipun zat-zat tersebut aman untuk dikonsumsi dan tidak mempengaruhi kalori maupun gula darah, secara tidak langsung akan menyebabkan pengaruh fungsi tubuh dalam jangka waktu panjang. Akan lebih bijaksana kita menyayangi tubuh kita dengan menjaga kesehatan dengan mengkonsumsi bahan makanan alami yang tidak berdampak buruk pada tubuh kita.

Pertanyaan yang diberikan di atas merupakan contoh beberapa butir pertanyaan yang terdapat pada Tugas 1, Tugas 2 dan Tugas 3 tutorial online. Terdapat 5 sampai 6 butir pertanyaan pada setiap tugas. Pertanyaan yang diberikan mengacu pada jenjang kemampuan berfikir sesuai dengan taxonomy Bloom's. Hampir seluruh mahasiswa mampu menjawab dengan baik, walaupun dengan ulasan yang agak berbeda. Adapun sebaran hasil Tugas 1, Tugas 2 dan Tugas 3 tuton Kimia Lingkungan pada masa ujian 2010.2-2012.2 seperti tertera pada Gambar 3.

Skor terendah diperoleh mahasiswa pada Tugas 1 adalah 75 dan tertinggi 98 dengan nilai rata-rata sebesar 86,39. Untuk Tugas 2 skor terendah 65 dan tertinggi 99 dengan nilai rata-rata 87,67. Selanjutnya untuk Tugas 3 skor terendah 70 dan tertinggi 95, dan skor rata-rata 87,73. Melalui angka-angka tersebut dapat diterangkan bahwa mahasiswa telah mampu menjawab tugas yang diberikan. Hampir seluruh mahasiswa menjawab pertanyaan dengan kalimat yang bervariasi namun mempunyai arti yang sama, dan diduga mahasiswa menggunakan berbagai sumber bacaan untuk mempelajari materi Kimia Lingkungan.

Pertanyaan yang terdapat pada tugas tuton terdiri atas pertanyaan ingatan, pemahaman, penerapan, analisis, evaluasi dan kreasi. Pada pertanyaan ingatan, pemahaman dan penerapan umumnya dapat dijawab dengan mudah oleh mahasiswa, sementara untuk pertanyaan yang menuntut berfikir lebih tinggi belum semua mahasiswa mampu menjawabnya. Sebagai contoh pada pertanyaan nomor 4 yaitu "Apakah penipisan lapisan ozon ada hubungannya dengan Pemanasan Global dan Perubahan Ikllim?", terdapat jawaban yang berbeda diberikan oleh mahasiswa. 

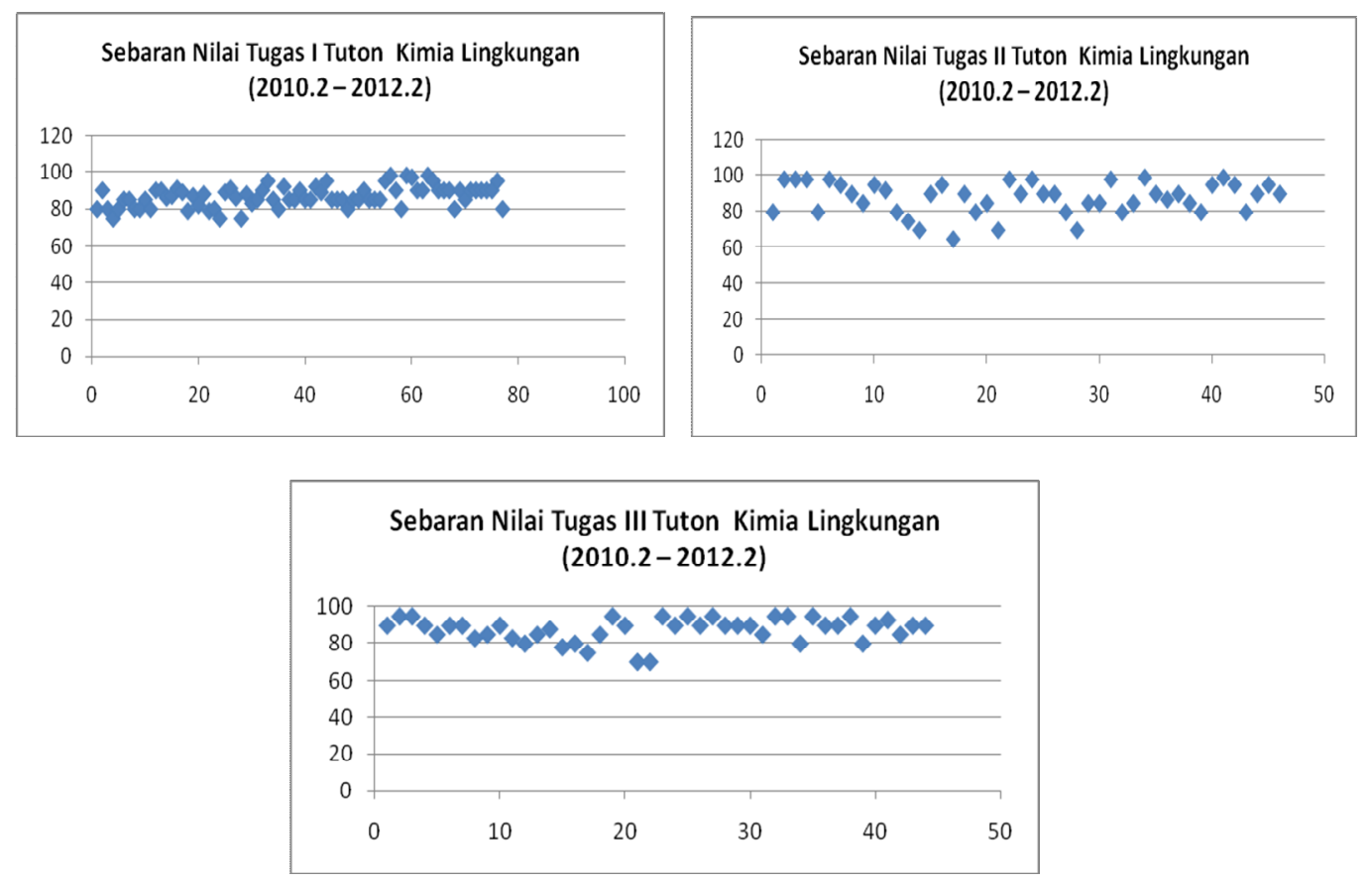

Gambar 3. Sebaran nilai tugas tuton mahasiswa pada masa registrasi 2010.2-2012.2 (sumber: data tuton ut)

Ada jawaban mahasiswa yang dijabarkan dengan lengkap, namun ada pula mahasiswa yang menjawab sangat singkat bahkan tanpa analisis, seperti tertera pada Tabel 2. Sementara melalui pertanyaan tersebut diharapkan mahasiswa dapat melakukan suatu evaluasi, dimana mahasiswa sebelumnya diharapkan telah mengerti maksud pemanasan global dan maksud perubahan iklim. Selanjutnya mahasiswa dapat menggunakan proses berfikir nalarnya dengan membuat suatu analisis keterkaitan antara pemanasan global dan perubahan iklim, sehinggga diperoleh suatu penilaian. Pada tahap ini mahasiswa dapat melakukan analisis berbagai bacaan yang mendukung, sehingga mahasiswa dapat membuat suatu kesimpulan yang benar dalam berargumentasi. Sementara pada pertanyaan butir 6 kepada mahasiswa diminta untuk mencari suatu artikel terkait materi yang diajarkan, dan artikel tersebut diminta untuk diulas sesuai dengan pemahaman mahasiswa atas artikel/bacaan tersebut. Pada kegiatan ini mahasiswa dilatih untuk berkreasi memilih sendiri artikel yang disukai dan mengulasnya sesuai dengan pemahamannya. Melalui pemberian tugas dan penyelesaian tugas oleh mahasiswa diharapkan mahasiswa dapat berlatih untuk memilih artikel/bacaan ilmiah dan berlatih "berargumen" berdasarkan pemahamannya secara tertulis. Pada umumnya mahasiswa dapat memilih artikel/bacaan yang relevan sesuai butir pertanyaan, akan tetapi masih cukup banyak mahasiswa belum mampu membuat ulasan tentang artikel yang dipilihnya sendiri.

Nilai akhir tutorial online terlihat pada Gambar 4, yang menunjukan bahwa skor tertinggi adalah 96 dan skor terendah 41, dengan rata-rata skor adalah 71. Sebaran skor terbanyak berada pada kisaran 71 sampai dengan 90, selanjutnya pada kisaran 50 sampai dengan 70 . Terdapat pula sejumlah mahasiswa yang memperoleh skor di bawah 50. Hal ini disebabkan mahasiswa tidak mengumpulkan seluruh tugas tuton yang dipersyaratkan serta ada tugas yang tidak dikumpulkan/di 
upload. Sementara mahasiswa yang memperoleh skor lebih dari 90, umumnya mengumpulkan seluruh tugas dan mampu memberikan uraian jawaban dengan lengkap.
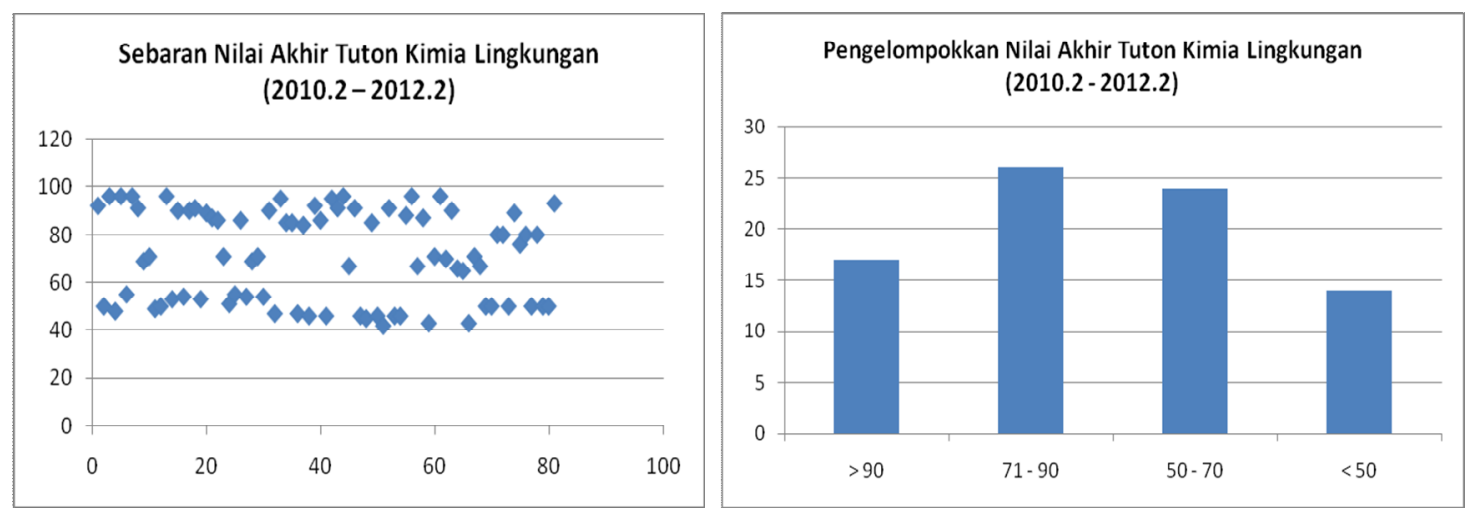

Gambar 4. Pencapaian nilai akhir tutorial online matakuliah kimia lingkungan

Selain bentuk pertanyaan yang diberikan dalam tugas bersifat pertanyaan langsung seperti tertera pada Tabel 2, kepada mahasiswa diberikan pula pertanyaan dalam bentuk kasus. Soal dalam bentuk "kasus" dengan jenjang kemampuan C5 (Evaluasi) seperti tertera pada contoh berikut.

"Analisis air sumur 3 wilayah A, B dan C mendapatkah hasil seperti tertera pada Tabel 3 berikut. Jelaskan bagaimana kondisi air sumur untuk wilayah $A, B$ dan $C$ berdasarkan data yang tertera. Selain itu jelaskan pula berapa batas yang diperkenankan / layak digunakan sebagai air minum dari setiap parameter sesuai dengan Keputusan Menteri Kesehatan Republik Indonesia"

Tabel 3. Hasil Analisis Kandungan Air

\begin{tabular}{|c|c|c|c|c|}
\hline PARAMETER & SATUAN & \multicolumn{3}{|c|}{ HASIL } \\
\hline & & A & B & C \\
\hline Rasa & - & Berasa & Tidak berasa & Tidak berasa \\
\hline Bau & - & Berbau & Tidak berbau & Tidak berbau \\
\hline Kekeruhan & mg SiO2/ & 112,5 & 12,5 & 185 \\
\hline $\mathrm{pH}$ & - & 7,90 & 7,25 & 7,59 \\
\hline $\mathrm{BOD}_{5}$ & ppm & 8,30 & 1,44 & 4,11 \\
\hline COD & ppm & 15,05 & 2,40 & 8,18 \\
\hline $\mathrm{PO}_{4}$ & $\mathrm{ppm}$ & 0,255 & 1,70 & 0,402 \\
\hline Amoniak & ppm & 0,190 & 0,056 & 0,110 \\
\hline E Coli & $\begin{array}{l}\text { E.Coli//0 } \\
0 \mathrm{m1}\end{array}$ & 28 & 0 & 3 \\
\hline Coliform & $\begin{array}{l}\text { Co1ifoa } \\
\mathrm{m} / 100 \mathrm{m1}\end{array}$ & 1100 & 240 & 1000 \\
\hline $\begin{array}{l}\text { Kondisi Air } \\
\text { Sumur }\end{array}$ & & ? & $?$ & $?$ \\
\hline
\end{tabular}


Melalui pertanyaan dalam bentuk "kasus", diperlukan suatu kemampuan membaca, memahami, menganalisis bacaan atau data dengan baik sebelum menjawab pertanyaan. Pada umumnya mahasiswa belum mampu menjawab soal dalam bentuk "kasus", dan terdapat kurang dari $60 \%$ mahasiswa yang mampu menjawabnya dengan baik atas pertanyaan yang diberikan.

Rendahnya angka ini diduga mahasiswa belum terbiasa dengan soal dalam bentuk "kasus" sehingga mahasiswa kurang mampu menjawab pertanyaan yang diberikan (Sandra \& Hamda, 2012).

\section{Respon Mahasiswa pada Kegiatan Tutorial online}

Kegiatan tutorial online matakuliah Kimia Lingkungan, umumnya direspon baik oleh mahasiswa, termasuk terhadap ajakan tutor untuk menggunakan berbagai sumber bacaan yang dapat diunduh dari "open educational resources". Tanggapan mahasiswa tersebut seperti tertera pada contoh respon mahasiswa berikut.

1. Mahasiswa A: "Menyenangkan sekali bisa memperoleh ilmu dan pengetahuan baru, meskipun tidak membaca langsung dari buku tetapi bisa mendapatkan ilmu dari berbagai sumber internet yang beragam. Hal ini akan sangat berguna untuk memperluas sumber informasi tentang berbagai ilmu pengetahuan tanpa adanya batas ruang dan waktu. Dengan men-download dari internet, biaya yang dikeluarkan lebih murah daripada harus membeli diktat.

Tetapi kadang ketika dalam men-download ada kendala yang saya hadapi misalnya, ada sumber yang susah untuk di-download, ada juga sumber informasi yang sekiranya lengkap tapi harus mendaftar dahulu yang kadang prosesnya membingungkan".

2. Mahasiswa B: "Tugas yang diberikan sangat bermanfaat untuk menambah pengetahuan umum mengenai lingkungan yang berhubungan dengan kimia. Dengan adanya tugas untuk mendownload materi dari internet, semakin menambah pengetahuan tentang fenomena-fenomena yang terjadi di lingkungan sekitar".

3. Mahasiswa C: "membantu pemahaman materi mata kuliah lingkungan dan mendapat informasi/tambahan pengetahuan dari open source (tugas) yang diberikan".

\section{PENUTUP}

Tutorial online sebagai salah satu bantuan belajar yang diberikan dalam sistem pendidikan jarak jauh selain digunakan untuk meningkatkan kemampuan belajar mahasiswa juga untuk membangun komunikasi antara tutor dengan mahasiswa atau antar mahasiswa. Melalui inisiasi serta tugas yang diberikan diharapkan mahasiswa akan terlatih untuk membaca dan menelusuri bacaan sehingga memahami suatu konsep yang sedang dipelajari.

Kegiatan tutorial online matakuliah Kimia Lingkungan, selama empat masa registrasi yaitu 2010.2, sampai dengan 2012.2 yang diselenggarakan oleh program Pendidikan Kimia FKIP-UT menunjukkan adanya partisipasi mahasiswa. Mahasiswa mampu merespon permintaan tutor untuk menggunakan berbagai sumber bacaan yang tersedia dalam open education resource, meskipun terdapat sebagian mahasiswa masih mengalami kendala waktu dalam mengerjakan tugas karena kesibukannya sebagai guru dan mahasiswa. Namun demikian mahasiswa telah mampu menjawab pertanyaan, baik yang tergolong pada jenjang berfikir tingkat rendah maupun jenjang berfikir tingkat tinggi dengan bantuan berbagai sumber bacaan.

\section{REFERENSI}

http://farr-integratingit.net/Theory/CriticalThinking/revisedcog.htm; 27 Nov 2011 http://student.ut.ac.id/mod/statut 
http://media.ccconline.org/ccco/FacWiki/TeachingResources/Blooms Taxonomy Tutorials/BloomsTa xonomy Verbs Pyramid/BloomsTaxonomyVerbsPyramid.swf, Februari 2014.

L.W. Anderson \& D.R. Krathwol. (2001). A taxonomy for learning teaching and assessing. A revision of bloom,s taxonomy of educational objectives. New York: Addison Wesley Longman, Inc.

Sandra, S. A., \& Sri Hamda. (2012). Pembelajaran kimia melalui kegiatan tutorial on line. Seminar nasional kimia dan pendidikan kimia, 25 Februari 2012 UNESA, Surabaya.

Sandra, S. A, \& Tita Rosita. (2012). The analysis of students' task answer at on-line tutorial activities of environmental chemistry subject, AAOU 26th Annual conference of asian association of Open Universities, 16-18 October 2012 Chiba: Japan.

Tim Simintas. (2004). Pedoman penyelenggaraan tutorial. Universitas Terbuka. 